\title{
Ideological Counter-Narrative as a Response to Fundamentalist Ideology in Europe and South Asia. An Analysis of Selected Cases in Their Cultural Context and an Outline of Recommended Activities*
}

\author{
Piotr KŁODKOWSKI \\ Anna SiewiersKa-ChmaJ
}

\begin{abstract}
The article discusses the issues of religious radicalisation and de-radicalisation in contemporary Islam. Its authors present complex phenomena of ideological, historical, cultural and political contexts of radicalisation processes, investigate the distribution of radical propagandist materials among various Muslim communities around the world and analyse the consequences of ideological transformation of Islamic fundamentalism in selected European countries. The authors conclude that radicalisation propaganda has a global appeal due to the fact it has adopted a carefully selected group of globally recognised ideologues (Ibn Abd al-Wahhab, Abul A'la Maududi, Sayyid Qutb), but the recommended de-radicalisation processes should be rooted locally or regionally. The article proposes a constructive theoretical framework, a working hypothesis that should be constantly revised and modified in the changing socio-political environment.
\end{abstract}

KEYWORDS: RADICALISATION, de-radicalisation, Islamic fundamentalism, Internet, cognitive closure, counter-narrative

Piotr KŁodкowski, PhD Professor of Jagiellonian University in Kraków, former Ambassador of Poland to India and Sri Lanka (20092014), member of the Consultative Council "Muslim Perspectives" published by Muslim Institute (Pakistan), Visiting Professor at University of Rochester (USA). 
$\underline{\text { KŁODKOWSKI, SieWIERSKA-ChmaJ, Ideological Counter-Narrative... } 88}$

iD https://orcid.org/0000-0001-9273-8560

E-MAIL: piotr.klodkowski@uj.edu.pl

Anna Siewie Rska-Chmaj, PhD Professor and Rector of the Tischner European University in Kraków.

iD https://orcid.org/0000-0001-7943-3746

E-MAIL: ASiewierska@wse.krakow

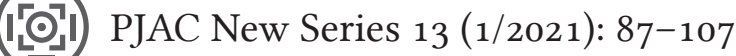


$\underline{\text { KŁODKOWSKI, SieWIERSKA-ChMAJ, Ideological Counter-Narrative... } 89}$

\section{Introduction}

Although radicalisation does not seem to be a new phenomenon, it has been analysed more intensively after a series of terrorist attacks carried out in Western and Asian countries, including the United States, the United Kingdom, Spain, France, India or Sri Lanka in 2001-2009. The concept of radicalisation has no longer remained a mere academic issue, but also entered wider public discourse, at the same time losing the precision of its definition. One of the few statements repeated from different perspectives is that radicalisation is a process by which an individual or a group adopts increasingly extreme views. Other definitions have most often only served to obscure the issue, making everything look like radicalisation or, quite the opposite - like nothing at all. Unclear or even erroneous conceptualisations do not help form accurate diagnoses, as in the case of radicalisation, thrown into one bag with the notions of political extremism, religious fundamentalism and even Islamic terrorism. ${ }^{1}$

A great number of analyses made at that time focused on the structural factors of radicalisation (poverty, social exclusion, increased inequalities, etc.), marginalising or ignoring other mechanisms conditioning the phenomenon of radicalisation, which are especially relevant if we want to find a universal, cross-cultural pattern illustrating the process of transforming a reasonable human being into an individual prepared to brutally kill innocent people. Finding such a pattern seems to be extremely important if we consider the growing number of terrorist attacks carried out by so-called lone wolves, individuals often not belonging to any extremist organisations, but only inspired by their ideology. An excessive and exclusive focus on the political, economic or religious causes of radicalisation makes it difficult to see that the rise of radicalism is occurring not only among Muslims, but in general this is a global tendency observed in various religious and national groups, largely associated with the media, especially the so-called new media (Awan, Hoskins, and O'Loughlin 2011, 1-25; Sawicka 2017). The phenomenon has been analysed by the European Parliament's Culture and Education Commission, preparing guidelines for the European Parliament motion for the resolution

* This publication in English is a modified and updated version of the paper originally published in Polish „O koncepcji ideologicznej kontrnarracji wobec przesłania fundamentalizmu islamskiego: analiza wybranych przykładów radykalizacji i deradykalizacji w Europie, Azji Południowej i na Bliskim Wschodzie,” „Sprawy Międzynarodowe,” vol. 72, No 1, 2019.

1 Problems related to conceptualisation of research on radicalisation are discussed inter alia by: Rik Coolsaet (2011), Arun Kundnani (2012) and Alex P. Schmid (2013). 
on the prevention of radicalisation and recruitment of European citizens by terrorist organisations (2015/2063(INI)). The report draws attention not only to the use of the Internet and social media by terrorist organisations to disseminate propaganda and recruitment materials, which seems quite obvious, but it calls on the EU Member States to actively prevent the spread of radical content and propaganda on the Internet and to implement programs for disseminating knowledge among young people about hate speech on the Internet and related threats. The Commission emphasises the need to conduct educational activities aimed at disseminating media and promoting Internet literacy, noting that it is necessary to develop both critical judgment skills in the digital environment among all vulnerable Internet users, and technologies that will help control and take preventive actions against radicalisation. Although the prepared document does not explicitly refer to the predispositions of the "digital generation," pushing it towards extremisms of various kinds, it emphasises the role of education:

In helping young people to understand and accept differences in opinions, beliefs, worldviews and lifestyles, while respecting their diversity and the rule of law, in promoting critical thinking and proper assessment, in order that they should know, particularly in the context of the Internet and social media, how to understand the reality, to distinguish facts from opinions, to recognize propaganda and to resist all forms of indoctrination, hate speech and online extremism (Report on the prevention... 2015).

\section{Radicalisation, Internet and New Media}

Many studies show that it is the youngest group of voters who are moving away from democracy towards various kinds of "-isms:" populism, extremism, fundamentalism, etc. (Decker, Kiess, and Brähler 2016; Mounk and Foa 2017; Inglehart et al. 2018). It is probably not a coincidence that this is also the same group that uses the Internet and new media to the greatest extent, and simultaneously obtains from them most of their information about the world (Allcott and Gentzkow 2017). In this context, it is easy to understand why the Egyptian authorities should be more afraid of Millennials than the Islamic State (Schwartzstein 2019), and George Soros at the Davos Economic Forum in January 2018 called for regulation of the largest monopolists in the Internet industry, among them Facebook and Google, warning against a situation in which the power and possibilities of shaping the worldview of 
young people is concentrated in the hands of several global companies. "It takes a real effort to assert and to defend what John Stuart Mill called 'the freedom of mind'," suggested Soros in his speech, as "there is a possibility that once lost, people who grow up in the digital age will have difficulty in regaining it," and "people without the freedom of mind can be easily manipulated" (Oppenheim 2018). Is the currently observed procession of all kinds of extreme behaviour, not only in the political dimension but also in every other area, really associated with the loss of "freedom of mind"? And how does one interpret this allegedly lost freedom?

Although it is not difficult to share Soros' anxiety about the monopolistic position of Internet corporations, simultaneously, the proposed prescription brings the same longing for some unspecified glorious past, for some lost sense, which is sought by both supporters of populism and ideologists of modern jihad. It is just that a de-mythologised history calls into question the logic of such thinking: centuries of devastating wars, crimes against humanity, plundering exploitation of natural resources, and such examples can be multiplied indefinitely. Turning exclusively to the past for a key to solving today's problems may turn out to be not only futile but even risky in some cases, and is like putting out a fire with gasoline. Indeed, history provides us with some knowledge, but this knowledge is - in our opinion more about what should not be done, what should be strongly avoided to prevent political or social disaster. Some specific questions referring to the "sanctified past" can tell us more about the potential areas of political manipulation rather than about some opportunities to fit former solutions into the present times:

- Which part of our collective memory can be purposefully mythologised and used for political purposes?

- Which historical figures can be easily put on a pedestal, only to hide our own persons and our own political ideas behind them?

- Which ancient values should be dusted off so that they may become instruments for validating a "new and just" order?

Let us admit that history is full of tragedies and threats with numerous incarnations that can affect modern man and even entire societies - but hardly ever (if at all) can they be substantial signposts for the future.

New media can potentially impoverish not so much our (real or only postulated), freedom, but above all, and this probably is the greatest threat, our way of thinking and our knowledge that is thought to be the foundation of true wisdom. Consequently, as Amin Maalouf rightly puts 
KŁODKOWSKI, SieWIERSKA-ChMAJ, Ideological Counter-Narrative... 92

it in Le dérèglement du monde [Deregulation of the World], "to accept ignorance is to renounce democracy, to reduce it to appearances" (Maalouf 2011, 147).

Analysing both the phenomenon of radicalisation from the generational perspective of Generation Y and the impact of the Internet and new media helps to avoid the intellectual and political trap that awaits those who may be tempted to identify radicalisation exclusively with Islam or any other religion. At the same time there is no doubt that Muslims are the most radicalised religious group, just as Christians (equally Protestants, Catholics and the Orthodox) were the most radicalised group in 19th-century Europe. This situation compels us to posit another question: does research on the 19th-century radical movements which called for profound social, political and moral changes, many of which were factually implemented like suffrage of women, the eight-hour workday, etc., bring anything fresh and informative to our knowledge on the contemporary issue of radicalism? Not much, it seems.

\section{Radicalisation in Muslim Communities}

Alex S. Wilner and Claire-Jehanne Dubouloz note that the radicalisation of Muslims is taking place on two different levels. Before the attacks on the World Trade Center, most terrorist acts had been prepared and conducted by people radicalised in their social and cultural circles, in principle somewhere outside the Euro-Atlantic civilisation; only the last act - the attack - was directed against a Western state. After 2001, the phenomenon called indigenous terrorism or "homegrown terrorism" (decidedly more devastating) began to spread, and was most often aimed at civilians, posing a huge challenge for security agencies (Wilner, Duboulozb 2010, 33). According to Edwin Bakker's research, out of 200 jihadists, $90 \%$ were residents of European countries, and $60 \%$ were citizens of a European state (Bakker 2006, 36-7). An analysis of the biographies of the so-called "homegrown terrorists" from 2005-2007 clearly indicates that their radicalisation and the decision to become actively involved in terrorist activities took place in Europe, mainly due to propaganda disseminated on the Internet and through social media. Magdalena Adamczuk, a member of National Security Bureau of Poland, puts forward a slightly controversial thesis, which we will argue with: 
The radicalisation process is unique for each person, making it difficult to define a terrorist profile and characteristics. In passing through particular phases of radicalisation, it is difficult to find any logical sequences of events, although usually the process begins among young people who look for their identity and often find it by identifying themselves with the ideology of Islamism (Adamczuk 2011, 67).

It can be concluded that both the pace and extent of radicalisation increases with access to the Internet and the new media, which allow for easier transmission of radical content (Bergen 2016). It is much simpler because Internet-based recommendation techniques and codes tracking users' online activity allow the authors of the ideological message to determine users' interests, and thus to personalise the "prompted" content, regardless of whether this is gardening advice or Islamist propaganda. The prompted messages are positioned in such a way as to best suit a specific user (Leavitt 2006, 15-18).

\section{The ideological, political and social context of radicalisation}

Widespread and barely controlled distribution of fundamentalist propaganda in social media is a necessary condition, but is naturally insufficient in the process of radicalisation of potential recipients. No less important are the political and socio-cultural contexts that foster the development of the radicalism ideology. The issues of the security of the religious community, the defence of the values of the professed religion, or even more - of the perceived threat to cultural and religious identity - are not easy to define precisely, hence they are convenient in building extremely ideological narratives by fundamentalist groups.

A report prepared in 2013 by Wissenschaftszentrums Berlin für Sozialforschung (WZB), based on research conducted in six EU countries (including France and Germany) presents the whole ideological spectrum of contemporary European Muslims. Two-thirds of Muslim believers say that their religious laws are more important than laws of a particular country, and three-quarters do not allow pluralism in understanding of the Koran, recognising that there should be only one, undisputed interpretation (in contrast, the opinions regarding the Bible expressed by European Christians are $13 \%$ and $20 \%$ respectively). As many as $45 \%$ of the Muslim respondents are openly anti-Semitic, and a similar number declare that "the West intends to destroy Islam." Among 
Christian respondents who are convinced that "Islam intends to destroy the West" these figures are $9 \%$ and $23 \%$ respectively. The authors of the report conclude that the classic ideas of fundamentalism find very fertile ground among European Muslims. Besides, the very thesis of the report is striking: "(In Europe) Islamic religious fundamentalism is widespread” („Islamischer religiöser Fundamentalismus ist weit verbreitet") (Wissenschaftszentrum Berlin für Sozialforschung 2013). It is difficult to explain clearly the reasons for such a phenomenon, but it can be hypothetically assumed that the conjunction of the EU's active foreign policy towards Muslim countries and the prevailing post-religious concept of a secular state in Europe is significant here, which might be perceived by Muslim believers as a threat rather than an opportunity for cultivating religious values. The radical interpretation of the social position of one's own religious community and the posed (real or imaginary) threat to it is further strengthened by the message of social media, which easily crosses international borders and contributes to building an ideological alliance over ethnic and linguistic divisions among Muslims. In this situation, closer cooperation and a sense of religious community among descendants of migrants from Bangladesh and Pakistan in the United Kingdom, Algeria and Morocco in France, and Turkey in Germany (who have previously had very little in common apart from their professed religion) takes on a new character and becomes even a symbol of "Islam over frontiers", and this in turn allows for a more effective diffusion of propaganda materials across the whole continent.

The migration crisis which has affected the countries of Western and Southern Europe is unlikely to change anything in the approach of the surveyed Muslim group, especially since subsequent waves of migration have contributed to the electoral success of extreme right-wing parties and groups, leading the mainstream parties to a shift in migration policies (Krause, Abou-Chadi 2018). The order of events should be clearly emphasised here: the quoted research was conducted before the largest migration wave in 2015 and in the following years (which in turn contributed to the increase in the popularity of European right-wing parties) and not after they occurred. In other words: the fundamentalist tendencies among Muslims in the surveyed countries of the European Union had been present for many years before the public opinion of the Old Continent had been influenced by right-wing ideology, so they are not an ideological response to this phenomenon, although neither it is possible to say arbitrarily that they are one of the most important reasons for its origin. 
The radicalisation process in Europe is obviously not an isolated phenomenon, separate from events in the Middle East, North Africa and South Asia. It is strongly connected with the phenomenon of popularisation of various types of fundamentalism initiated even before the Second World War, e.g. in Egypt, where the Muslim Brotherhood organisation was founded, and in British India where one of the most influential ideologues of the movement, Abul A'la Maududi (Mawdudi) was preaching (A'la Maududi 1932; Vali Reza Nasr 1996). For a relatively long time, fundamentalists of various ideological persuasions did not pose a serious threat to the stability of Muslim countries (and indirectly to Europe as well); only the events of the last thirty years have helped them to rise out of a small ideological niche and onto the main stage of history. Jihad in Afghanistan as a consequence of Soviet aggression, the Islamic revolution in Iran, the civil war in Algeria, then the Western intervention in Afghanistan and Iraq, and finally the Arab Spring with all its consequences all this has organisationally, ideologically and financially strengthened a few extreme Muslim groups enormously, which have been able to impose their own vision of the world on the conquered (even temporarily) territories in Iraq, Syria, Afghanistan and Pakistan. On the other side there are authoritarian or semi-authoritarian regimes in North Africa and parts of the Middle East, which, on the one hand, reject the radical interpretation of religion, but on the other retain (or try hard to do so) their strict control over the entire state machinery. Political authoritarianism appears to be the real price for stopping the extreme fundamentalist trend. The European Union countries (primarily France and the United Kingdom, but also - to a lesser extent -Germany, Spain and Italy) have had to develop "business as usual" relations with, and thus legitimise, some authoritarian regimes in particular regions of Islamic civilisation, and in extreme cases - most often in cooperation with the United States - have elected to intervene militarily, for example in Afghanistan, Iraq and Libya. Such actions constitute an obvious pretext for fundamentalist organisations to formulate radical messages, in which the aim of aggression on many levels becomes a chosen state, its inhabitants, institutions or symbols (public burning of flags, destruction of emblems, etc.). In addition, the message is reinforced with information about discrimination, real or only imaginary, against the Muslim minority in a chosen European country or - very generally - throughout the West, which is presented as an "enemy of Islam."

2 Cf. an evolution of radicalism in Islam and an analysis of the propaganda language in: Emmanuel Sivan (1990), Gilles Kepel (1997; 2005; 2017), Bernard Lewis (2003). The European context is analysed in Piotr Kłodkowski (2016). 


\section{The psychological dimension of radicalisation processes}

Technological capabilities in the distribution of effective propaganda and political and socio-cultural contexts, are not enough, however, to explain the sources of radicalism, especially in its extreme version: terrorism motivated by religious ideology. The growing number of supporters of fundamentalism among European Muslims, as presented by the results of the WZB research, does not necessarily mean a dramatic increase in the number of people adhering to any active radicalism, i.e., accepting violence and bloodshed. For example, recruitment conducted by the so-called Islamic State (ISIS) in Europe probably did not exceed five thousand people, although estimates provided by Europol in 2015-2017 should be verified again (Teffer 2015). Even if we assume that the actual number of active radicals prepared to use terrorist methods is two or three times higher - which would not be shocking - it is still equivalent to the per mille number of the entire Muslim community on the Old Continent. Naturally, from the point of view of those in charge of state security, these data must be alarming and ought to lead to te initiation of appropriate actions.

The basic issue is the answer to the question about the motivation of individual ISIS volunteers, their psychological profile, and their personality profile. Adamczuk (2011), quoted above, suggests that motivation is a highly individual matter, and the process of radicalisation in the case of individuals can proceed in many ways. Of course, at a certain level of generality, it is difficult to negate the simple fact that each person is unique and behaves in a manner typical of himself or herself. However, in such a situation it is impossible to explain why ISIS propaganda turned out to be quite effective and why using these and no other arguments and promises succeeded in convincing certain groups of young men (much less frequently women) to join the ranks of a terrorist organisation. Here, we refer to the research and conclusions of Arie Kruglanski, who presented the psychological profile of a "radicalized person," ready to use violence formally justified by the professed ideology. In the quoted article, Kruglanski focuses on the ISIS phenomenon, but it is worth noting that his research is also relevant for other cultural areas, including Sri Lanka, where for decades the radical Tamil Tigers organisation was very active (cf. Kruglanski et al., 2009). Kruglanski writes: 
From a psychological perspective, the appeal of violent extremism derives from a clever exploitation of two basic human needs: the need for cognitive closure and the need for personal significance. The need for closure amounts to the quest for certainty [in life], and the eschewal of [any] ambiguity; it is the desire to feel assured about the future, to know what to do and where to go. It is the quest for [proper] structure and coherence in one's outlook and beliefs (Kruglanski 2014).

Both needs are the foundation of human experience, he emphasises; nevertheless, the intensity of their bearing on everyday existence depends on the political and social context. In times of mass migration, clashes of different cultures, economic recession, and the breakdown of the current order in many countries of the Middle East and North Africa, the feeling of growing uncertainty and fears for their own future or the future of their family or community (let us add: the real or ideologically postulated one) ${ }^{3}$ is becoming the dominant feeling of an increasing number of people, especially migrants from areas of Islamic civilisation. It is not surprising that then the need for closure is like a psychological balm creating an illusion of an orderly world of values, eliminating the perceived pain of the surrounding chaos and helplessness. The ideological course offered by radical fundamentalist groups fits well with these needs. Kruglanski explains:

They do so by painting a Manichean worldview characterized by sharp dichotomies and clear choices; a world of good versus evil, saints versus sinners, order versus chaos, a pure universe in black and white admitting no shades of grey. A fundamentalist ideology establishes clear contingencies between actions and consequences; it offers a future that is predictable and controllable. Such a perspective holds particular fascination for confused youths in transitional stages of their lives, who drift like rudderless ships and find themselves torn by conflicting cultural demands (Kruglanski 2014).

The concept of cognitive closure also perfectly explains the growing number of politically updated myths becoming the backbone of ideologies, especially the fundamentalist ones (Siewierska-Chmaj 2016).

Research conducted by the US Department of Defense and the National Science Foundation emphasises a strong correlation between the need for

3 The fundamentalist propaganda materials often refer to "real Muslims," which simply means their actual or potential supporters. The rest, though they form a large part of the believers, are rejected as those who live in the era of "modern-day jahiliyyah" (religious ignorance). The author of the concept of "contemporary jahiliyyah" is Sayyid Qutb (died in 1966). 
cognitive closure and extremism. Importantly, the results are not limited to Muslim countries (e.g. Morocco, Palestine), but also include Sri Lanka and Northern Ireland, where the issues of internal conflicts refer more to the past than to the present. Taking into consideration the elements of universalism explained in that research, it should be emphasised that while these conflicts in Europe and South Asia are classified as local, the issue of extremism in individual Muslim countries is more global and concerns the areas of the Middle East, North Africa (partly also its sub-Saharan part) and, increasingly, Europe itself. ${ }^{4}$

The need for cognitive closure is closely related to the aforementioned need for personal significance. Kruglanski (2014) points out that in its propaganda ISIS offers potential fighters metaphysical (and, to a degree, political) rewards that meet psychological needs. In the struggle against "infidels" (which often include Muslims who do not share radical views) the fighters gain the status of martyrs and heroes, along with their reserved place in history. They are to create a "new chapter in the history of Islam" they even become "an instrument in the hands of God," and their actions are supposed to gain acceptance among zealous believers. Obviously, elevating raising a potential fighter to such a metaphysically elevated status is in practice impossible to achieve in ordinary everyday life, often marked by poverty and lack of perspective, and by the usual boredom of routine activities performed for years. The authors of the message to future jihadist fighters use proven propaganda techniques, which although formally refer to metaphysics, are in fact based on the aforementioned psychological needs described years ago by Maslow. Abu Yahya al-Libi, coming from Libya and officially associated with al-Qaeda, is the author of a widespread appeal to the faithful in Algeria, in which he calls for the overthrow of the "infidel" government. Thus, he says:

This path, and I mean the path of jihad, despite the catastrophes, sufferings, hardships and all forms of anguish [which appear on it], is a path that pleases the Almighty God and is a sign of supreme obedience to Him. This is the proof of God's true love and the distinction between people of honesty and faith from people of deceit and deception. The path of jihad is a way of cleansing the ranks of Muslims and a means of maintaining the banner of true monotheism and the total elimination of unbelief and all profanation. ${ }^{5}$

4 The issues of regionalism and globalization of fundamentalism were already addressed by Bassam Tibi, himself a Muslim by birth (cf. Bassam 2002).

5 Al-Qa'ida Abu-Yahya al-Libi Calls on Algerians To Fight Against 'Infidel' Government, 2009. Arie Kruglanski also refers to this document in his article. Some phrases of radical fundamen- 
This type of propaganda enunciation is additionally strengthened by appealing to the most real or sometimes imaginary suffering of Muslims: whether in Afghanistan or Iraq after the US intervention, or in Algeria, Libya or Egypt because of one or another foreign policy of France, the United Kingdom or the European Union as a whole, or among European Muslims who - according to propagandists - experience persecution or discrimination. The target of the attack may also be a theoretically Muslim government, as in the cases of Algeria and Egypt, which allegedly do not respect the teachings of Islam and are believed to be influenced by Western ideology. The already quoted Abu Yahya al-Libi, otherwise considered a gifted poet and orator, calls in another part of the message:

Jihad in Algeria is your hope today, and thanks to the Almighty it will liberate [us] from the hell of unjust governments, whose prisons are full of youth adolescents and children, and even your women (Al-Qa'ida... 2009).

The promise of gaining glory and the status of a martyr is associated here with the idea of a fight for justice and avenging all wrongs, which naturally strengthens the propaganda message itself. An interesting element in this context is the element of struggle against one's own coreligionists, which also characterised ISIS in its activities in Syria and Iraq. This is not a novelty, because the philosophy of internal struggle has existed in Islam almost since the very beginning of its existence, and in the zoth century it gained a modern interpretation. According to the extreme fundamentalists, the ideological archenemy was once Kemal Atatürk, the founder of the Turkish Republic, and in Egypt King Farouk, then presidents Nasser, Sadat and, to a lesser extent, Mubarak. It was they who opposed the radicalism of the Muslim Brotherhood, albeit in a way that was resisted by the Egyptians themselves. Muhammad Abd al-Salam Faraj, one of the leading Salafi ideologists, head of the radical group Tanzim al-Jihad, and co-responsible for the plot to assassinate President Anwar Sadat, presented his own philosophy in brutally clear words: "Fighting the closer enemy is much more important than fighting the distant enemy. So, in our jihad we will shed the blood of Muslims until we reach the final victory" (Al-Jihād: al-Farīda al Ghā'iba, as quoted in Lewis 2003, 120).

talists recall the phrases from "Catechism of a Revolutionary" by Sergey Nechayev, coming from a completely different era and other culture. Cf. parallels with revolutionary movements in Europe in Tismăneanu (2014). 
Kruglanski points to yet another element present in the ISIS propaganda, which was part of the "psychological package" in the process of recruiting future fighters. It is about the valorisation of the most primitive instincts aggression and sex drive - which are supposed to be met within the ranks of the organisation. ISIS, as he explains, created a "well-lubricated sex machine" for its own volunteers, using so-called marital centres in which women registered themselves (often coerced by violence) to marry a chosen fighter. Thanks to specially devised fatwas, running "houses of pleasure" in Iraq was legalised, where the female supervisors were foreign volunteers and the victims of rapes were mainly non-Muslims. According to Nadia Murad, in 2014 alone about seven thousand women, followers of Yezidism, were kidnapped from the northern province of Sinjar and were brutally forced to have sex with ISIS members. The promises of sexual experiences did not end with the mundane life: fragments of the Koran were interpreted as literally promising the martyrs access to beautiful virgins after reaching paradise (Murad 2017).

Obviously, violence against women and mass rapes have always been and still continue to be a macabre component of war or terrorist activities almost anywhere in the world and in any historical period, but it is worth turning attention to a very important element that distinguishes ISIS from others. The aforementioned "sexual jihad" had a metaphysical and legal sanction, and thus was supposed to relieve more pious Muslims of any possible remorse. Of course, the issued fatwas were negated by most Muslim jurists, but within ISIS - in accordance with the principle of cognitive closure - another principle of interpreting the law of Islam and its metaphysical message was functioning and was readily accepted. This allowed the use of violence in an unfettered, hampered manner and on a large scale.

Arie Kruglanski concludes that the successes of ISIS - as a relatively small terrorist organisation - were of both a military and psychological nature (let us add also the logistical aspect and the ability to skilfully exploit social media, without which global recruitment would not behave been possible at all), which allowed them to properly compose the entire propaganda package. The principles of cognitive closure and personal significance combined with the exploitation of primitive human instincts have proven extremely effective in recruiting volunteers and motivating them to use their newly discovered violence, and it is possible that even after the final defeat of ISIS they will be used by other fundamentalist organizations in various areas of the globe. 


\section{The process of de-radicalisation - an outline of action}

The process of de-radicalisation itself is extremely complex and depends on cultural, political, ideological and psychological conditions. It should be implemented in several areas that overlap, and its effectiveness depends on the inclusion of cultural and political differences. In other words, what is accepted, for example, in Pakistan or among the Pakistani community in Europe will not necessarily gain understanding in Saudi Arabia or Morocco. Of course, the fact that one has to deal with the cultural, ethnic and linguistic complexity of the Islamic civilisation as a whole or the ethno-linguistic diversity of Muslim communities in Europe (e.g. the community in Bradford, originating in from the Indian sub-continent, or the Arabic one in Marseille, etc.) does not mean that we exclude some generalisation of arguments, but it tends to indicate to the multiplicity of possible options, which may be applicable depending on the aforementioned political and cultural context.

At the political macro level - that is, the overall policy regarding the area beyond the European limes, it is difficult to argue reasonably with the thesis that uncontrolled migration from Muslim countries has a negative impact on the stability and security of the EU countries. Humanitarian aspects naturally have their weight, but they should in no way override the issue of protecting the lives and health of local citizens or residents, which is, or at least should be, the priority for any government in the Realpolitik world. This is one of the politically most difficult and morally most sensitive challenges that nearly the entire European Union will have to face in the coming years.

Another task is to analyse the foreign policy of EU Member States visà-vis individual Muslim countries. Here the possibilities of significant adjustment are quite limited. It is very risky and quite ineffective to suspend or even significantly restrict relations with authoritarian governments in North Africa or the Middle East, i.e., in the areas of strategic importance for Europe, albeit mainly for its southern and western regions. It is worth emphasising, however, that the EU - as a whole - has less and less (or even no) influence on the internal situations in the region and cannot be held responsible for the brutal actions initiated by local governments. Diplomatic protests because of human rights violations or limited economic sanctions should be the only option to choose. The dramatic consequences of the armed intervention in Libya, and earlier in Iraq, should make it clear that the military option finally led to the total or partial disintegration of the two countries, and in no way did it improve security on a regional scale. 
The intervention in Iraq, and subsequent internal struggles, cost the lives of nearly 200,000 people, with many Muslims blaming this mainly on the United States and its allies. Even if we do not fully agree with such reasoning, we must consider that such a narrative about "Western responsibility" is a strong argument in the propaganda of fundamentalist organisations (Iraq Body Count n.d).

In our opinion, we might be able to take actions against some radical factions of Islam in the "ideological war" by promoting an appropriate counter-narrative, with its structure and content derived from respected Muslim communities not necessarily living in Europe. At this point, we provide the little-known example of Pakistan, one of the largest Muslim countries, and one which is also perceived negatively perceived in Europe and the United States. De-radicalisation activities were initiated by the Pakistani government and the army as part of the "Zarb-e-Azb" campaign, although their direction and further actions would depend on the current political situation. To put it in a simplified way: it is about propagating the ideology of Islam (and thus the ideology of the state itself), developed by the founding fathers Muhammad Ali Jinnah and Muhammad Iqbal, in opposition to Maududi's fundamentalist concepts, which has been zealously disseminated in the country since the presidency of Zia-ul-Haq. ${ }^{6}$ Iqbal, considered one of the greatest Muslim philosophers of the zoth century and the author of the concept of liberal Islam, accepts the democratic system (albeit not in the Anglo-Saxon, or more broadly Western version), and rejects the philosophy of violence justified by religion. ${ }^{7}$ In turn, Jinnah is the actual founder of modern Pakistan, which - in his vision - was intended to be a tolerant state, open (to some extent) to ideas originating from beyond the civilisation of Islam. The political and religious heritage of both iconic figures is recalled by, inter alia, Pakistan's current Prime Minister, Imran Khan, head of Pakistan's Tehreek-e-Insaf Party, an Oxford graduate and formerly a world-leading class cricket player. It is difficult to say what shapes this ideological dispute will take, but it is nevertheless worth working out the significance of the narrative model used here. On one hand, we have an ideology well-settled in the mo-

6 While the military aspect of "Zarb-e-Azb" has been comprehensively illustrated in the media and official documents, de-radicalisation at the ideological and psychological level is still the subject of a broad discussion. Not only state institutions take part in it, but also religious authorities, such as the Muslim Institute, with which the authors of the article cooperate.

7 This is first about his publication Islam as an Ethical and Political Ideal (Iqbal, Hashimy 1955). A detailed view of contemporary Islam can be found in his treatise: The Reconstruction of Religious Thought in Islam (Iqbal 1934). 
dern understanding of Islam, developed by political and religious icons, and on the other hand, a fundamentalist version of religion, associated (though not always directly) with Abu A'la Maududi. The proper way of promoting a more liberal interpretation of Islam, one with a strong legitimacy of tradition and with the help of contemporary religious authorities, has the chance to gradually reduce the ideologies of violence and fanaticism, symbolised by factions of local Taliban who have threatened the stability of the state. This is a task which may take a relatively long time to implement, but it should guarantee a high level of credibility among most Muslims.

The described model naturally has some limitations. While the ideology of fundamentalism, largely due to social media has a global reach largely due to social media, and it often appeals to the same religious authorities as Ibn Taymiyya, Muhammad ibn Abd al-Wahhab, Sayyid Qutb or the aforementioned Maududi, the proposed counter-narrative is usually of a local character: iconic figures like Iqbal and Jinnah would enjoy authority in Pakistan itself (and possibly among the Muslim community in the United Kingdom) but, e.g. they would not gain understanding in Kuwait, Oman or Morocco, where both are little-known or hardly reliable have little credibility. ${ }^{8}$ In the case of the European Union as a whole, the issue of building a counter-narrative should rest on local Muslim communities and respectful theologians (under moderate state supervision); we recognise that it is unlikely that a pan-European concept could be created, one equally credible for the linguistically and ethnically diverse European communities of Islam. Nevertheless, the goal for all should be to formulate a philosophy of multidimensional European Islam, ideologically compatible with the system of liberal democracy. The role of the state in the whole process should be significant, although deliberately reserved in some areas. The official acceptance of the message of counter-narrative and its authoritative figures is a necessity, although in this area secular institutions should leave ample room for interpretation by the selected ulama, otherwise the entire process would not gain the necessary credibility among believers. The makers of this potential counter-narrative ought to consider the issues analysed by Arie Kruglanski in order to satisfy the need for cognitive closure of the faithful and their personal significance. Here, cooperation between ulama and experienced psychologists (preferably

8 It is worth mentioning that Iqbal in his work Islam as an Ethical and Political Ideal (1955) criticised every system of hereditary power, hence his analysis of the structure of the state based on the philosophy of Islam will not be enthusiastically received by members of the authorities in states with a monarchical system, i.e. in Saudi Arabia, Morocco or Oman. 
Muslims or at least cooperating with Muslim communities) who specialise in researching the phenomena of radicalism would be a must. The tasks of the democratic state also include assistance in the wide distribution of all counter-narratives and effective blocking of the radical content flow on social media or on generally accessible web pages. In a world of free speech and the free flow of billions of bits of information, this may seem impossible, but a lack of action in this area may result in the failure of the entire project. And a final remark: a fairly active role of official institutions in the process of creating a counter-narrative of a religious character may cause rather poor associations among a significant number of secular Europeans attached to the principle of the ideological neutrality of the state. The British, or rather Anglo-Saxon, philosophy of the state not interfering with any religious problems and leaving them to be decided by religious communities is considered the most appropriate. The problem is that such a philosophy, widely approved and praised in many EU countries, has enabled the effective promotion of the globalised message of fundamentalism in Europe, most often in the Wahhabi version, which is indirectly confirmed by the quoted WZB survey and later research by the Pew Research Center (PRC). Currently, the EU countries are inhabited by an Islamic community of 25 million, and according to one of the three scenarios developed by the PRC, their number may triple by 2050 , while in Germany alone this would mean an increase from $6.1 \%$ of the total population in 2016 to $19.7 \%$ thirty-four years later. ${ }^{9}$ The lack of appropriate actions by European Union Member States might result in gradual, though unevenly distributed, radicalisation of the entire Muslim community, which in turn could lead to an ever greater social acceptance of the nationalist radicalism manifested by the extreme right, contributing, as we assume, to the final disintegration of the European Union. The political resort to the artificial blurring of cultural boundaries often results - paradoxically - in the erection of much higher ideological walls. A similar scenario, although with different political implications, may also develop in South Asian countries, where the socio-cultural structure is no less complex than in Europe. And the example of ideological confrontation in Pakistan should be the subject of further, in-depth research. We are convinced that such a scenario, today difficult to imagine, would materialise in the absence of decisive de-radicalisation activities.

9 Cf. the issues of three scenarios concerning the Muslim community in Europe, analysed in the report by the Pew Research Center (Lipka 2017). 


\section{Bibliography}

A’la Maududi, Abdul. 1932. Risālah-e-Dīnīyat. Lahore.

Adamczuk, Magdalena. 2011. "Rodzimy terroryzm jako zjawisko zagrażające bezpieczeństwu w Europie.” Bezpieczeństwo Narodowe 1: 61-80.

Allcott, Hunt, and Matthew Gentzkow. 2017. "Social Media and Fake News in the 2016 Election." Journal of Economic Perspectives 31, no 2: 211-236.

Al-Qa'ida Abu-Yahya al-Libi Calls on Algerians to Fight Against 'Infidel' Government. 2009. Accessed August 22, 2018. https://scholarship.tricolib.brynmawr.edu/bitstream/ handle/10066/4707/AYL20090622.pdf?sequence $=4$.

Awan, Akil N., Andrew Hoskins, and Ben O'Loughlin. 2011. Radicalisation and Media: Connectivity and Terrorism in the New Media Ecology. London: Routledge. https://doi. org/10.4324/9780203829677.

Bakker, Edwin. 2006. Jihadi Terrorists in Europe: Their Characteristics and the Circumstances in Which They Joined the Jihad. Hague: Netherlands Institute of International Relations.

Bergen, Peter. 2016. Jihad 2.0: Social Media in the Next Evolution of Terrorist Recruitment, presented by the U.S. Senate Committee on Homeland Security and Governmental Affairs. Washington: US Government Publishing Office. Accessed July 5, 2021. https:// archive.org/details/gov.gpo.fdsys.CHRG-114shrg95653.

Coolsaet, Rik, ed. 2011. Jihadi Terrorism and the Radicalisation Challenge: European and American Experience. Farnham: Ashgate Publishing.

Decker, Olivier, Johannes Kiess, and Elmar Brähler. 2016. Die enthemmte Mitte: Autoritäre und rechtsextreme Einstellung in Deutschland. Gießen: Psychosozial-Verlag.

Inglehart, Ronald, Christian Haerpfer, Alejandro Moreno, Christian Welzel, Kseniya Kizilova, Juan Diez Medrano, Marta Lagos, Pippa Norris, Eduard Ponarin, and Bi Puranen et al., eds. 2018. World Values Survey: Round Six - Country-Pooled Datafile. MadridVienna: JD Systems Institute \& WVSA Secretariat. https://doi.org/10.14281/18241.8.

Iqbal, Muhammad. 1934. The Reconstruction of Religious Thought in Islam. Oxford: Oxford University Press.

Iqbal, Muhammad. 1955. Islam as an Ethical and Political Ideal. Lahore: Orientalia.

Iraq Body Count. Accessed August 28, 2018. https://www.iraqbodycount.org/database/.

Kepel, Gilles. 1997. Allah in the West: Islamic Movements in America and Europe. Stanford: Stanford University Press.

Kepel, Gilles. 2005. The Roots of Radical Islam. London: Saqi Books.

Kepel, Gilles. 2017. Terror in France: The Rise of Jihad in the West. Princeton: Princeton University Press.

Kłodkowski, Piotr. 2016. "Nowy spór o uniwersalia, czyli o wspólnocie muzułmańskiej w Europie XXI wieku." In W pułapce wielokulturowości, edited by Anna Siewierska-Chmaj, 31-51. Warszawa: Wydawnictwo Uniwersytetu Warszawskiego.

Krause, Werner, and Tarik Abou-Chadi. 2018. Radical Right Success and Mainstream Parties' Anti-Immigrant Policy Shifts. Accessed August 23, 2018. https://democracy.blog. wzb.eu/2018/07/17/radical-right-success-and-mainstream-parties-anti-immigrant-policy-shifts.

Kruglanski, Arie W. 2014. "Psychology Not Theology: Overcoming ISIS' Secret Appeal.” E-International Relations. Accessed August 26, 2018. https://www.e-ir.info/2014/10/28/ psychology-not-theology-overcoming-isis-secret-appeal/. 
Kruglanski, Arie W., Jocelyn J. Bélanger, Michele Gelfand, Rohan Gunaratna, Malkanthi Hettiarachchi, Fernando Reinares, Edward Orehek, Jo Sasota, and Keren Sharvit. 2013. "Terrorism, A (Self)Love Story: Redirecting the Significance-Quest Can End Violence." American Psychologist 68: 559-575.

Kruglanski, Arie W., Xiaoyan Chen, Mark Dechesne, Shira Fishman, and Edward Orehek. 2009. "Fully Committed: Suicide Bombers' Motivation and the Quest for Personal Significance." Political Psychology 30: 331-357.

Kundnani, Arun. 2012. "Radicalisation: The Journey of a Concept." Race \& Class 54, no 2: 3-25.

Leavitt, Neal. 2006. "Recommendation Technology: Will it Boost E-Commerce?" Computer 5: 15-18. http://dx.doi.org/10.1109/MC.2006.176.

Lewis, Bernard. 2003a. The Crisis of Islam. Holy War and Unholy Terror. London: Random House Trade Paperbacks.

Lewis, Bernard. 2003b. What Went Wrong. Western Impact and Middle Eastern Response. London: W\&N.

Lipka, Michael. 2017. "Europe’s Muslim Population Will Continue to Grow - But How Much Depends on Migration.” Pew Research Center. Accessed August 28, 2018. http://www. pewresearch.org/fact-tank/2017/12/04/europes-muslim-population-will-continue-to-grow-but-how-much-depends-on-migration.

Maalouf, Amin. 2011. Rozregulowany świat. O kryzysie naszych cywilizacji. Translated by Wojciech Prażuch. Warszawa: Czytelnik.

Mounk, Yascha, and Roberto S. Foa. 2017. "The Signs of Deconsolidation.” Journal of Democracy 28, no 1: 5-16.

Murad, Nadia. 2017. The Last Girl. My Story of Captivity and My Fight against the Islamic State. New York: Penguin Random House.

Oppenheim, Maya. 2018. "Davos 2018: George Soros Launches Blistering Attack on Trump 'The survival of our entire civilisation is at stake.' Independent. Accessed January 26, 2018. https://www.independent.co.uk/news/world/europe/davos-2018-george-soros-launches-blistering-attack-trump-survival-our-entire-civilization-stake-george-soros-trump-davos-2018-speech-us-nuclear-war-civilisation-american-hungarian-a8179311.html.

Report on the Prevention of Radicalisation and Recruitment of European Citizens by Terrorist Organisations. 2015. Accessed January 3, 2018. http://www.europarl.europa. eu/doceo/document/A-8-2015-0316_EN.html.

Sawicka, Zofia. 2017. Wpływ nowych mediów na przemiany polityczne wybranych państw Bliskiego Wschodu na przykładzie Arabskiej Wiosny. Warszawa: Wydawnictwo Uniwersytetu Warszawskiego.

Schmid, Alex P. 2013. "Radicalisation, De-Radicalisation, Counter-Radicalisation: A Conceptual Discussion and Literature Review." The International Centre for Counter-Terrorism - The Hague 4, no 2. http://dx.doi.org/10.19165/2013.1.02.

Schwartzstein, Peter. 2019. "Egipska bomba demograficzna." Newsweek. Accessed May 4, 2021. https://www.newsweek.pl/swiat/egipt-boom-demograficzny-gorszy-niz-terroryzm-panstwa-islamskiego/chs8fx0.

Siewierska-Chmaj, Anna. 2016. Mity w polityce. Funkcje i mechanizmy aktualizacji. Warszawa: Aspra.

Sivan, Emmanuel. 1990. Radical Islam. Yale: Yale University Press. 
Teffer, Peter. 2015. "Up to 5,000 Europeans Joined Jihad, Europol Chief Says.” EUObserver. Accessed August 23, 2018. https://euobserver.com/news/127202.

Tibi, Bassam. 2002. The Challenge of Fundamentalism. Political Islam and the New World Disorder. Berkeley: University of California Press.

Tismăneanu, Vladimir. 2014. The Devil in History. Communism, Fascism and Some Lessons of the Twentieth Century. Berkeley: University of California Press.

Vali Reza Nasr, Seyyed. 1996. Mawdudi and the Making of Islamic Revivalism. Oxford: Oxford University Press.

Wilner, Alex S., and Claire-Jehanne Duboulozb. 2010. "Homegrown Terrorism and Transformative Learning: An Interdisciplinary Approach to Understanding Radicalization.” Global Change, Peace \& Security 22, no 1: 33-51. https://doi.org/10.1080/14781150903487956.

Wissenschaftszentrum Berlin für Sozialforschung. 2013. Islamischer religiöser Fundamentalismus ist weit verbreitet. Accessed August 22, 2018. https://www.wzb.eu/de/ pressemitteilung/islamischer-religioeser-fundamentalismus-ist-weit-verbreitet. 